\title{
SARS-CoV-2-Associated T-Cell Responses in the Presence of Humoral Immunodeficiency
}

\author{
Sudhir Gupta Houfen Su Tejal Narsai Sudhanshu Agrawal \\ Division of Basic and Clinical Immunology, University of California, Irvine, CA, USA
}

\section{Keywords}

Memory T and B cells · Follicular helper T cells · Regulatory lymphocytes · Plasmablasts · Germinal center B cells

\begin{abstract}
We report perhaps the most comprehensive study of subsets of CD4+ and CD8+ and subsets of B cells in a mild symptomatic SARS-CoV-2+ immunocompetent patient and a common variable immunodeficiency disease (CVID) patient who had normal absolute lymphocyte counts and remained negative for SARS-CoV-2 IgG antibodies. Naïve $\left(T_{N}\right)$, central memory $\left(T_{C M}\right)$, effector memory $\left(T_{E M}\right)$, and terminally differentiated effector memory ( $\mathrm{T}_{\text {EMRA }}$ ) subsets of CD4+ and CD8+ $T$ cells, subsets of $T$ follicular helper cells $\left(c T_{F H}, T_{F H} 1, T_{F H} 2\right.$, $\mathrm{T}_{\mathrm{FH}} 17, \mathrm{~T}_{\mathrm{FH}} 1 / \mathrm{T}_{\mathrm{FH}} 17$, and $\left.\mathrm{T}_{\mathrm{FR}}\right), \mathrm{CD} 4$ Treg, CD8 Treg, mature $\mathrm{B}$ cells, transitional B cells, marginal zone B cells, germinal center (GC) B cells, CD21 low B cells, antibody-secreting cells (plasmablasts), and Breg cells were examined in patients and agematched controls with appropriate monoclonal antibodies and isotype controls using multicolor flow cytometry. Different patterns of abnormalities (often contrasting) were observed in the subsets of CD4+ T, CD8+ T, B-cell subsets, and regulatory lymphocytes among the immunocompetent patient and CVID patient as compared to corresponding healthy controls. Furthermore, when data were analyzed be-
\end{abstract}

tween the 2 patients, the immunocompetent patient demonstrated greater changes in various subsets as compared to the CVID patient. These data demonstrate different immunological responses to SARS-CoV-2 infection in an immunocompetent patient and the CVID patient. A marked decrease in GC B cells and plasmablasts may be responsible for failure to make SARS-CoV-2 antibodies. The lack of SARS-CoV-2 antibodies with mild clinical disease suggests an important role of T-cell response in defense against SARS-CoV-2 infection.

(C) 2021 S. Karger AG, Basel

\section{Introduction}

SARS-CoV-2 infection (COVID-19) is pandemic with $>95$ million individuals infected, $>300,000$ new cases each day, and $>1$ million deaths worldwide. Following SARSCoV-2 infection, $>80 \%$ of individuals are asymptomatic or have mild disease [1]. However, $5-10 \%$ patients suffer with serious disease and another $5-10 \%$ with critical disease requiring admission to intensive care units and lifesupport measures with a high mortality rate. The serious disease appears to be, at least in part, due to "cytokine

Edited by: H.-U. Simon, Bern. karger@karger.com www.karger.com/iaa

(c) 2021 S. Karger AG, Basel

Karger ${ }^{\prime}=$
Sudhir Gupta

Division of Basic and Clinical Immunology, Medical Sciences I C-240, University of California at Irvine, Health Sciences Road Irvine, CA 92697 (USA)

sgupta@uci.edu 
storm" contributed predominantly by innate immune responses [2,3]. However, adaptive immune responses may contribute to clinical outcomes and severity of disease in a majority of infected individuals. Both antibody and Tcell responses have been studied in patients with COVID-19; however, most of these studies have been reported in severe disease and recovered patients, and very limited data are available for mild disease [3-16].

A number of changes in CD4+ T cell and CD8+ T cell number and functions, including CD4+ and CD8+ T cell lymphopenia, presence of activated $\mathrm{T}$ cells, increased or reduced exhausted $\mathrm{T}$ cells, dysregulated immune responses, and impaired cytotoxic responses, have been reported [3-17]; however, the role of T cells in mild disease and asymptomatic subjects is poorly understood.

Following antigenic stimulation, naïve $\mathrm{CD} 4+$ and CD8+ T cells $\left(\mathrm{T}_{\mathrm{N}}\right)$ undergo activation and clonal expansion to generate effector CD4+ and CD8+ T cells. This clonal expansion phase is followed by a phase of contraction due to apoptosis of effector T cells. A subpopulation of effectors cells is retained as long-term memory cells. Based upon their homing properties, and expression of adhesion molecules and chemokine receptors, memory $\mathrm{T}$ cells are classified into central memory $\left(\mathrm{T}_{\mathrm{CM}}\right)$ and effector memory $\left(\mathrm{T}_{\mathrm{EM}}\right) \mathrm{CD} 4+$ and $\mathrm{CD} 8+\mathrm{T}$ cells [18-26]. A small population of $\mathrm{T}_{\mathrm{EM}}$ cells reacquires CD45RA and is termed as terminally differentiated effector memory $\mathrm{T}$ cells $\left(\mathrm{T}_{\mathrm{EMRA}}\right)$. These subsets differ with regard to proliferative response, cytokine production, effector properties, and sensitivity to apoptosis [27-29].

Similar to T cells, the role of antibodies in the pathogenesis and clinical outcome in COVID-19 is not well understood. The majority of patients develop COVID-19 antibodies 1-2 weeks following SARS-CoV-2 infection, and increased circulating plasma cells have been reported $[14,30-33]$.

B-cell development initiates in the bone marrow from common lymphoid progenitors and undergo activation, proliferation, and differentiation in the lymph nodes and spleen [34-36]. Immature B cells leave the bone marrow as transitional B cells. Transitional cells represent a crucial step in the differentiation and selection of the mature B-cell compartment. Transitional B cells migrate to lymphoid follicles and a minor population to the marginal zone. In the follicle, antigen binding to the B-cell receptor activates $B$ cells. Antigen-activated B cells interact with follicular helper $\mathrm{T}\left(\mathrm{T}_{\mathrm{FH}}\right)$ cells, where they undergo proliferation and form germinal centers (GCs). In the GCs, B cells undergo immunoglobulin class-switch recombination and selection of high-affinity B cells. Subsequently, B cells leave the GCs to differentiate into long-lived plasma cells homing into the bone marrow to produce antibodies of different isotypes. A small population of GC B cells leaves the GCs to become class-switched memory (CSM) $\mathrm{B}$ cells. The marginal zone (MZ) B cells after interacting with antigens differentiate into short-lived antibody-secreting plasma plasmablasts [37], and a small population is retained as IgM memory B cells. IgM memory B cells, after interacting with antigen, undergo proliferation and differentiation to plasmablasts [38].

In this study, we present a comprehensive analysis of various subsets of $\mathrm{CD} 4+$ and $\mathrm{CD} 8+\mathrm{T}$ cells, subsets of $\mathrm{B}$ cells, and regulatory lymphocytes in an immunocompetent patient and a patient with common variable immunodeficiency disease (CVID) with mild COVID-19 disease and negative for SARS-CoV-2 antibodies.

\section{Materials and Methods}

A 22-year-old immunocompetent boy and a 63-year-old female CVID patient were studied simultaneously with age-matched healthy controls.

\section{Sample Preparation}

Peripheral blood was drawn from an immunocompetent patient (case \#1) and the CVID patient (case \#2) at 3 months after initial symptoms and when SARS-CoV-2 PCR was negative. Peripheral blood mononuclear cells (PBMCs) were isolated from blood of patient and age-matched healthy subjects by density gradient lymphocyte separation media. Human Subject Committee of the Institution Review Board of the University of California, Irvine, approved the protocol. A signed written consent was obtained from each subject.

\section{Antibodies and Reagents}

The following anti-human monoclonal antibodies were purchased from BD Biosciences (San Jose, CA, USA): anti-IgM APC, CD27 FITC, CD38 FITC, anti-IgD PE, CD21 PE, CD27 APC. CD19 PerCP, CD38 APC, CD24 FITC, CD4 PerCP, CD8 PerCP, CD45RA APC, CCR7 FITC, CD183 PE, CD25 FITC, CD127 AL647, FoxP3 PE, CD278 (ICOS) AL647, CD183 BV421, CXCR5 AL488, PD1 APC, CD8 BV421, and CD45RA BV510 were purchased from BioLegend (San Diego, CA, USA).

\section{Immunophenotyping}

Approximately 1 million PBMCs were used per combination for antibody staining. Twenty microliter of antibody were added to PBMCs for $30 \mathrm{~min}$. PBMCs were washed and fixed by $2 \%$ paraformaldehyde.

For regulatory cells: cells after surface staining were fixed and permeablized by FoxP3 staining buffer set (BD Bioscience) as per manufacturer's protocol and intracellular staining with antiFoxp3-PE monoclonal antibody, and appropriate isotype control (mouse IgG 1, k-PE) was used to evaluate nonspecific staining. All fluorescence minus one controls and isotype controls were stained 
and fixed by $2 \%$ paraformaldehyde for flow cytometry. Cells were acquired by BD FACS Celesta (Becton-Dickinson, San Jose, CA, USA) equipped with BVR laser. Forward and side scatters and singlets were used to gate and exclude cellular debris. Thirty thousand cells were acquired and analyzed using FLOWJO software (Ashland, OR, USA).

$B$ cell and B cell subsets were identified by following cell surface markers: naïve B cells - CD19+CD27-IgD+IgM+, transitional B cells-CD19+CD38+IgM++,MZBcells-CD19+CD27+IgD+IgM+, IgM memory B cells - CD19+/CD27+IgM+, GC B cells CD19+IgD-CD27+CD38+, class switch memory B cells CD19+CD27+IgD-IgM-, plasmablasts - CD19+CD38++IgM-, mature B cells - CD21 $1^{\text {high }} \mathrm{CD} 19+\mathrm{CD} 38-$, CD21 ${ }^{\text {Low }}$ cells CD19+CD38-CD21 low, and Breg - CD19+CD24+CD38+. Following cell surface phenotypes identified subsets of CD4 T cells and CD8+ T cells: $\mathrm{T}_{\mathrm{N}}-\mathrm{CD} 4+/ \mathrm{CD} 8+\mathrm{CD} 45 \mathrm{RA}+\mathrm{CCR} 7+, \mathrm{T}_{\mathrm{CM}}-$ CD4+/CD8+CD45RA-CCR7+, $\mathrm{T}_{\mathrm{EM}}-\mathrm{CD} 4+/ \mathrm{CD} 8+\mathrm{CD} 45 \mathrm{RA}-$ CCR7-, CD45RA+T $\mathrm{EM}_{\mathrm{EMRA}}$ - CD4+/CD8+CD45RA+CCR7-, CD8 Treg - CD8+CD183+CCR7+CD45RA-, and CD4 Treg CD4+CD25+CD127-FoxP3+. $\mathrm{T}_{\mathrm{FH}}$ cells were identified with the following markers: circulating $\mathrm{T}_{\mathrm{FH}}$ cells $\left(\mathrm{cT}_{\mathrm{FH}}\right)-\mathrm{CD} 4+$ / CXCR5+CD45RA-, $\mathrm{T}_{\mathrm{FH}} 1$ - CD4+CXCR5+CD45RA-CCR6CXCR3+ ${ }_{\mathrm{FH}} 2-\mathrm{CD} 4+\mathrm{CXCR} 5+\mathrm{CD} 45 \mathrm{RA}-\mathrm{CCR} 6-\mathrm{CXCR} 3-, \mathrm{T}_{\mathrm{FH}} 17-$ CD4+CXCR5+CD45RA-CCR6+ CXCR3, $\mathrm{T}_{\mathrm{FH}} 1+\mathrm{T}_{\mathrm{FH}} 17-\mathrm{CD} 4+/$ CXCR5+/CD45RA-/CCR6+/CXCR3+, and T follicular regulatory cells $\left(\mathrm{T}_{\mathrm{FR}}\right)-\mathrm{CD} 4+\mathrm{CCR} 5+\mathrm{CD} 45 \mathrm{RA}-\mathrm{CD} 25^{\text {high }} \mathrm{FoxP} 3+$.

\section{Results}

\section{Case 1}

A 24-year-old Caucasian male with history of asthma, allergic rhinitis, and autism was referred to immunology clinic for evaluation of recurrent infections. He reported multiple episodes of otitis media and sinus infections as a child. More recently, he reported having multiple episodes of pneumonia over the previous 2 years, confirmed on various chest $\mathrm{x}$-rays or CT chest. The consolidations would vary in location with resolution between episodes. He had no other infectious history and had never been hospitalized for infection previously. His asthma was well controlled on low inhaled corticosteroid and montelukast, and his allergic rhinitis was well controlled on nasal fluticasone. He had no family history of immunodeficiency. He was investigated for primary immunodeficiency. Data of laboratory evaluation are shown in Table 1. No evidence of immune deficiency including specific antibody response was observed.

During the time he was undergoing immune evaluation, he developed 1 week of fever, cough, hoarseness of voice, and mild shortness of breath. Initially, he was given azithromycin with no improvement. A few days later, he was seen in the emergency room where chest $\mathrm{x}$-ray showed mild peribronchial thickening with mild bibasi-
Table 1. Immunological features of case 1

\begin{tabular}{|c|c|c|}
\hline Laboratory test & Value & $\begin{array}{l}\text { Reference } \\
\text { range }\end{array}$ \\
\hline \multicolumn{3}{|l|}{ Immunoglobulins, mg/dL } \\
\hline $\operatorname{IgG}$ & 1,301 & $610-1,616$ \\
\hline $\operatorname{IgM}$ & 90 & $35-242$ \\
\hline $\operatorname{Ig} \mathrm{A}$ & 259 & $84-499$ \\
\hline \multicolumn{3}{|l|}{ IgG subclasses, mg/dL } \\
\hline IgG1 & 662 & $382-929$ \\
\hline IgG2 & 490 & $242-700$ \\
\hline IgG3 & 40 & $22-176$ \\
\hline IgG4 & 36 & $5-125$ \\
\hline \\
\hline $\begin{array}{l}\text { against Streptococcus pneumoniae } \\
\text { post Pneumovax-23 administration }\end{array}$ & $13 / 23$ & $12-22 / 23$ \\
\hline Diptheria Ab IgG, IU/mL & 1.3 & $>0.1$ protective \\
\hline \multirow{2}{*}{\multicolumn{3}{|c|}{ Lymphocyte subsets, $/ \mathrm{mm}^{3}$}} \\
\hline & & \\
\hline Lymphocyte\% & 28 & $14-44$ \\
\hline Absolute lymphocytes & 8,300 & $4,000-10,500$ \\
\hline $\mathrm{CD} 3+\mathrm{CD} 4+\%$ & 51 & $24-64$ \\
\hline $\mathrm{CD} 3+\mathrm{CD} 4+$ number & 1,185 & $477-1,634$ \\
\hline $\mathrm{CD} 3+\mathrm{CD} 8+\%$ & 33 & $12-45$ \\
\hline $\mathrm{CD} 3+\mathrm{CD} 8+$ number & 767 & $168-1,315$ \\
\hline $\mathrm{CD} 4+/ \mathrm{CD} 8+$ ratio & 1.54 & $0.8-5.0$ \\
\hline CD3\% & 84 & $58-89$ \\
\hline $\mathrm{CD} 3+$ number & 1,952 & $700-2,377$ \\
\hline $\mathrm{CD} 19+\mathrm{B} \%$ & 9 & $6-29$ \\
\hline CD19+ B number & 209 & $104-795$ \\
\hline $\mathrm{CD} 56+\mathrm{NK} \%$ & 5 & $2-32$ \\
\hline CD56+ NK number & 116 & $43-680$ \\
\hline NK function (LU30) & 11 & $7-125$ \\
\hline Mannose-binding lectin, ng/mL & 263 & $\geq 100$ \\
\hline Complement $\mathrm{CH} 50$ & 110 & $60-144$ \\
\hline \multicolumn{3}{|l|}{ Isohemagglutinin titers } \\
\hline Anti-B IgM titer & $1: 16$ & $>1: 32$ \\
\hline Anti-B IgG titer & $1: 16$ & $>1: 32$ \\
\hline
\end{tabular}

lar atelectasis. Nasal-pharyngeal swab was positive for SARS-CoV-2. He was oxygenating well on room air and was discharged home with supportive care. Three weeks later, he continued to have worsening shortness of breath, cough, and fatigue. Repeat chest $\mathrm{x}$-ray showed peribronchial thickening though CT chest was clear. At 6 weeks after his initial diagnosis of COVID-19, his respiratory symptoms persisted. Repeat nasal-pharyngeal swab was again positive for SARS-CoV-2. SARS-CoV-2 IgG antibodies were negative. CT chest was unremarkable. At 8 weeks after the initial positive SARS-CoV-2 test, he started to feel some improvement in symptoms; however, hoarseness of voice continued. Repeat nasal-pharyngeal swab was negative for SARS-CoV-2. However, SARS- 
Table 2. Immunological features of case 2 (CVID)

\begin{tabular}{|c|c|c|}
\hline Laboratory test & Value & $\begin{array}{l}\text { Reference } \\
\text { range }\end{array}$ \\
\hline \multicolumn{3}{|l|}{ Immunoglobulins, $\mathrm{mg} / \mathrm{dL}$} \\
\hline $\operatorname{IgG}$ & $599^{\mathrm{a}}$ & $610-1,616$ \\
\hline $\operatorname{IgM}$ & 159 & $35-242$ \\
\hline $\operatorname{Ig} A$ & $73^{\mathrm{a}}$ & $84-499$ \\
\hline \multicolumn{3}{|l|}{ IgG subclasses, mg/dL } \\
\hline IgG1 & $373^{\mathrm{a}}$ & $382-929$ \\
\hline IgG2 & $152^{\mathrm{a}}$ & $242-700$ \\
\hline IgG3 & $14^{\mathrm{a}}$ & $22-176$ \\
\hline IgG4 & 11 & $5-125$ \\
\hline \multicolumn{3}{|c|}{$\begin{array}{l}\text { Protective antibody titers }(\geq 1.3 \mathrm{mg} / \mathrm{mL}) \\
\quad \text { against Streptococcus pneumoniae post }\end{array}$} \\
\hline Pneumovax-23 administration & $7^{\mathrm{a}} / 23$ & $12-22 / 23$ \\
\hline \multicolumn{3}{|l|}{ Lymphocyte subsets, $/ \mathrm{mm}^{3}$} \\
\hline Lymphocyte\% & 20 & $14-44$ \\
\hline Absolute lymphocytes & 1,780 & $900-3,300$ \\
\hline $\mathrm{CD} 3+\mathrm{CD} 4+\%$ & $78^{\mathrm{a}}$ & $31-61$ \\
\hline $\mathrm{CD} 3+\mathrm{CD} 4+$ number & $1,388^{\mathrm{a}}$ & $338-1,194$ \\
\hline $\mathrm{CD} 3+\mathrm{CD} 8+\%$ & 17 & $10-38$ \\
\hline $\mathrm{CD} 3+\mathrm{CD} 8+$ number & 303 & $85-729$ \\
\hline $\mathrm{CD} 4+/ \mathrm{CD} 8+$ ratio & $4.58^{\mathrm{a}}$ & $0.9-3.7$ \\
\hline $\mathrm{CD} 3 \%$ & $94^{\mathrm{a}}$ & $62-84$ \\
\hline CD3+ number & 1,673 & $619-1,847$ \\
\hline $\mathrm{CD} 19+\mathrm{B} \%$ & $3^{\mathrm{a}}$ & $5-26$ \\
\hline CD19+ B number & 53 & $51-473$ \\
\hline CD56+ NK\% & 3 & $1-17$ \\
\hline CD3-CD16+CD56+ NK number & 53 & $12-349$ \\
\hline \multicolumn{3}{|l|}{ Isohemagglutinin titers } \\
\hline Anti-B IgM titer & $1: 8$ & $>1: 32$ \\
\hline Anti-B IgG titer & $1: 8$ & $>1: 32$ \\
\hline
\end{tabular}

CVID, common variable immunodeficiency disease. ${ }^{\text {a }}$ Abnormal results.

CoV-2 IgG antibodies remained undetected. Sixteen weeks after his initial COVID-19 diagnosis, repeat SARSCoV-2 IgG antibodies were checked at a different lab and was still not detected; however, hoarseness of voice still persisted.

\section{Case 2}

A 64-year-old female was evaluated for recurrent sinus infections and urinary tract infections. She had no family history of immunodeficiency. Immunologic workup was consistent with a diagnosis of CVID (Table 2). No evidence of comorbidity including bronchiectasis was present. She was started on IVIG treatment. Three weeks after her first IVIG infusion, she developed malaise, cough, and nasal congestion. Nasal-pharyngeal swab was positive for SARS-CoV-2. She had 3 positive nasal-pharynge- al swabs for SARS-CoV-2 over the next 2 months. However, her symptoms completely resolved. Three months after initial infection, she had 2 nasal-pharyngeal swabs negative for SARS-CoV-2. SARS-CoV-2 IgG antibody test was performed 3 times over a 3-month period and remained negative. Throughout this time, she continued to receive her IVIG treatments. The patient received no other treatments.

Alterations in Subsets of CD4+ T Cells and CD4 Treg in SARS-CoV-2 Infection

$T$ cells, based upon expression of chemokine receptors, homing pattern and function have been identified as naïve, central memory, effector memory, and terminally differentiated effector memory cells [18-24]. Therefore, we examine various subsets in both patients and age and gender-matched healthy controls. A flow cytograph is shown in Figure 1. Increased CD4+ $\mathrm{T}$ cells and $\mathrm{T}_{\mathrm{N}}$ cells were observed in both immunocompetent and CVID patients, as compared to simultaneously analyzed age and gender-matched healthy controls. However, decreased $\mathrm{T}_{\mathrm{CM}}$ cells and increased $\mathrm{T}_{\mathrm{EMRA}}$ cells were observed in the immunocompetent patient and not in the CVID patient. CD4+ Treg cells were similar in both patients as compared to controls.

Alterations in CD8+ T and CD8+ T Cell Subsets and CD8 Treg in SARS-CoV-2 Infection

Similarly to CD4+ T cells, we analyzed various subsets of CD8+ T cells. CD8+ T cells were increased in both patients. A flow cytograph is shown in Figure 2. CD8+ $\mathrm{T}_{\mathrm{N}}$ cells were markedly increased in the immunocompetent patient; however, they were comparable to control in the CVID patient. CD8+ $\mathrm{T}_{\mathrm{EM}}$ cells were decreased in both patients; however, CD8 $+\mathrm{T}_{\mathrm{EMRA}}$ cells were increased in the CVID patient and decreased in the immunocompetent patient. $\mathrm{CD} 8+\mathrm{T}_{\mathrm{CM}}$ cells were comparable to controls in both patients. CD8+ Treg in both patients were comparable to healthy controls.

$\mathrm{T}_{\mathrm{FH}}$ Cell Subsets and $\mathrm{T}_{\mathrm{FR}}$ Cells Are Altered

Differentially in SARS-CoV-2 Infection in the

Immunocompetent Patient and CVID Patient

$\mathrm{cT}_{\mathrm{FH}}$ cells play an important role in GC formation, immunoglobulin isotype switching, and differentiation of $B$ cells to immunoglobulin secreting cells [39-44]. The signature cytokine they produce is IL-21. However, based upon additional cytokines produced, $\mathrm{CT}_{\mathrm{FH}}$ have been further classified into $\mathrm{T}_{\mathrm{FH}} 1, \mathrm{~T}_{\mathrm{FH}} 2$, and $\mathrm{T}_{\mathrm{FH}} 17$ [45]. In addition, $\mathrm{T}_{\mathrm{FR}}$ cells regulate the function of $\mathrm{cT}_{\mathrm{FH}}$ cells [46]. 


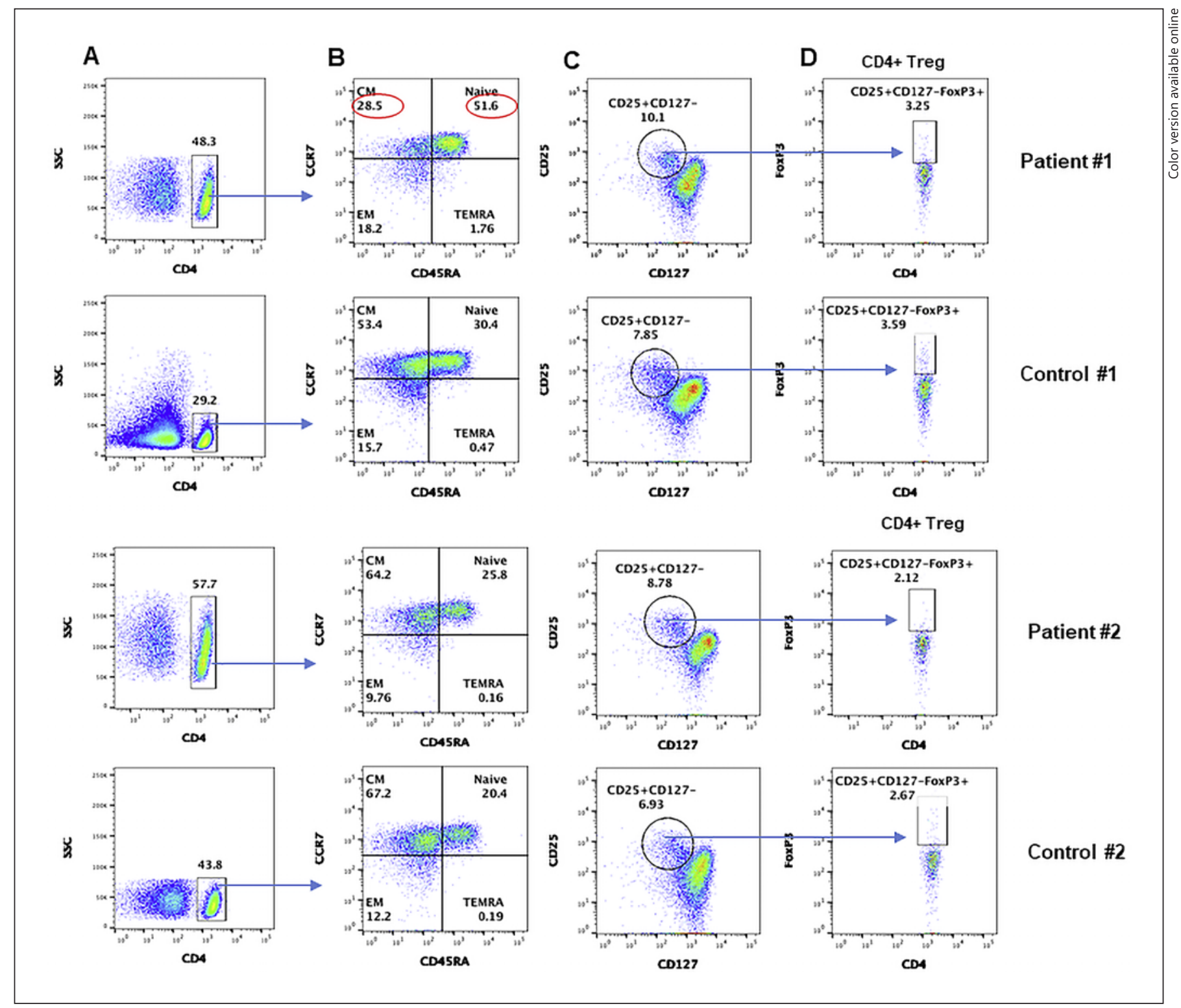

Fig. 1. A CD4 subsets: CD4+ gated cells in PBMCs, gated CD4+ cell subsets are characterized by different makers. B Gated CD4+ cells naïve: $\mathrm{T}_{\mathrm{N}}(\mathrm{CCR} 7+\mathrm{CD} 45 \mathrm{RA}+)$, central memory: $\mathrm{T}_{\mathrm{CM}}$ (CCR7+CD45RA-), effector memory: $\mathrm{T}_{\mathrm{EM}}$ (CCR7-CD45RA-), and $\mathrm{T}$ effector memory RA: $\mathrm{T}_{\mathrm{EMRA}}$ (CCR7-CD45RA+). C CD4

Therefore, we examined all subsets of $\mathrm{T}_{\mathrm{FH}}$. Pattern of changes is distinct between the immunocompetent patient and CVID patient. A flow cytograph is shown in Figure 3. Immunocompetent subject (case 1) had increased $\mathrm{T}_{\mathrm{FH}} 1, \mathrm{~T}_{\mathrm{FH}} 2$, and $\mathrm{T}_{\mathrm{FR}}$ cells and decreased $\mathrm{cT}_{\mathrm{FH}}$, $\mathrm{T}_{\mathrm{FH}} 17$ cells and $\mathrm{T}_{\mathrm{FH}} 1 / \mathrm{T}_{\mathrm{FH}} 17$ cells. In the CVID patient, $\mathrm{cT}_{\mathrm{FH}}$ and $\mathrm{T}_{\mathrm{FH}} 2$ cells were decreased, whereas $\mathrm{T}_{\mathrm{FH}} 1$ cells were increased. $\mathrm{T}_{\mathrm{FR}}$ cells were comparable to controls.

Subsets of CD4, CD8 T Cells, B Cells, and Regulatory Lymphocytes in COVID-19
Treg gated CD4+ cells for CD25+CD127-. D CD4+CD25+CD127FoxP3+ cells. Abnormal values are circled in red. PBMCs, peripheral blood mononuclear cells; $\mathrm{T}_{\mathrm{N}}$, $\mathrm{T}$ naïve; $\mathrm{T}_{\mathrm{EM}}$, $\mathrm{T}$ effector memory; $\mathrm{T}_{\mathrm{CM}}, \mathrm{T}$ central memory; $\mathrm{T}_{\mathrm{EMRA}}$, $\mathrm{T}$ effector memory $\mathrm{RA}$.

B Cells and B Cell Subsets, and Breg in SARS-CoV-2 Infection

Since both patients did not make antibodies to SARS$\mathrm{CoV}-2$, we analyzed B cells and various subsets of B cells in both patients and compared with healthy controls. A flow cytograph is shown in Figure $4 \mathrm{a}$ (case \#1) and Figure 4b (case \#2). CD19+ B cells in both patients were comparable to healthy controls. The immunocompetent patient 


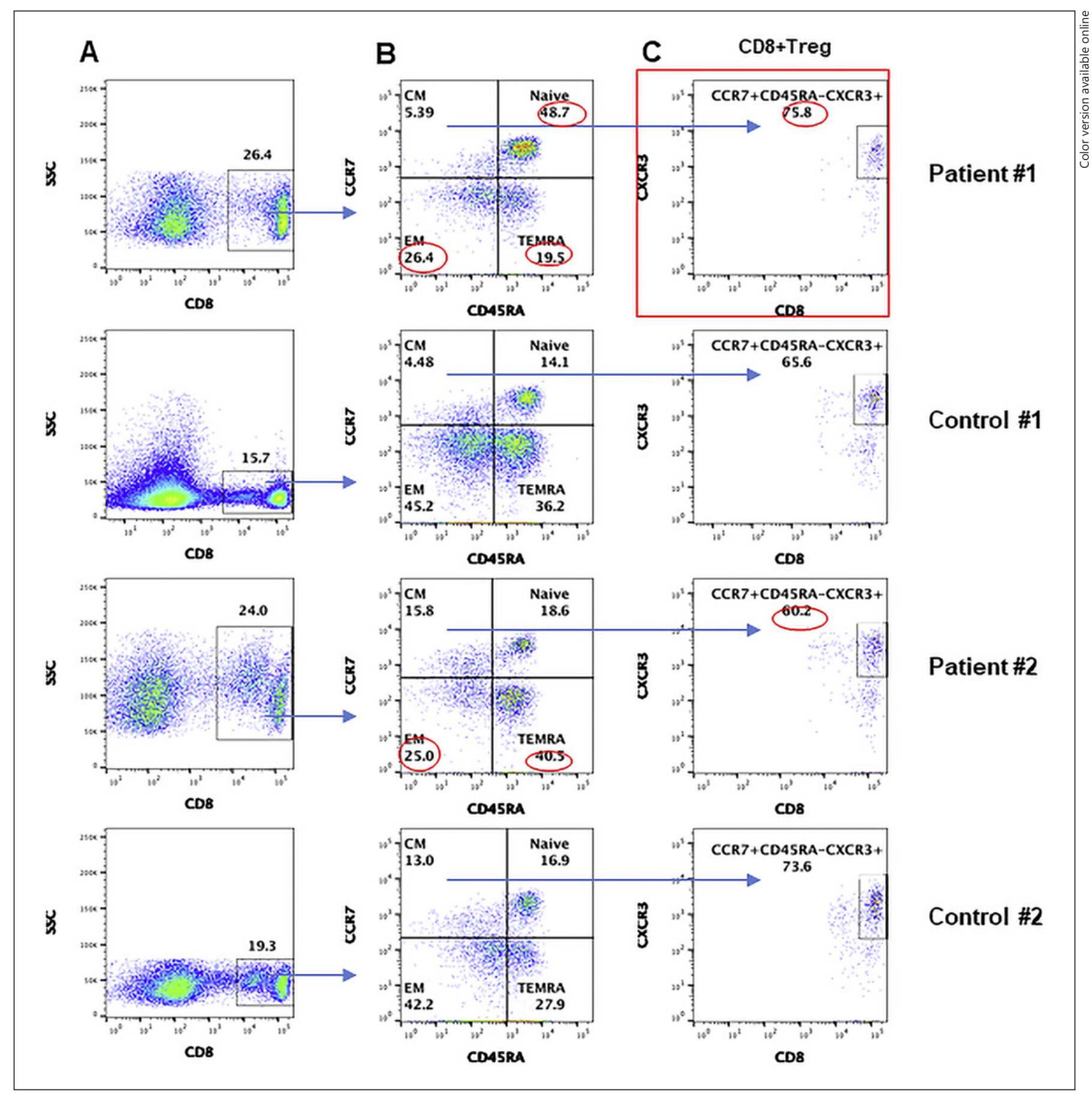

Fig. 2. A CD8 subsets CD8+ gated cells in PBMCs, gated CD8+ cell subsets are characterized by different makers. B Gated CD8+ cells $\mathrm{T}_{\mathrm{N}}(\mathrm{CCR} 7+\mathrm{CD} 45 \mathrm{RA}+), \mathrm{T}_{\mathrm{CM}}(\mathrm{CCR} 7+\mathrm{CD} 45 \mathrm{RA}-)$, $\mathrm{T}_{\mathrm{EM}}$ (CCR7-CD45RA-), and $\mathrm{T}_{\mathrm{EMRA}}$ (CCR7-CD45RA+). C CD8 Treg: gated CCR7+CD45RA- CD8 T cells expressing CD183 (CXCR3). Abnormal values are circled in red. PBMCs, peripheral blood mononuclear cells; $\mathrm{T}_{\mathrm{N}}$, T naïve; $\mathrm{T}_{\mathrm{EM}}, \mathrm{T}$ effector memory; $\mathrm{T}_{\mathrm{CM}}$, $\mathrm{T}$ central memory; $\mathrm{T}_{\mathrm{EMRA}}$, $\mathrm{T}$ effector memory RA. 


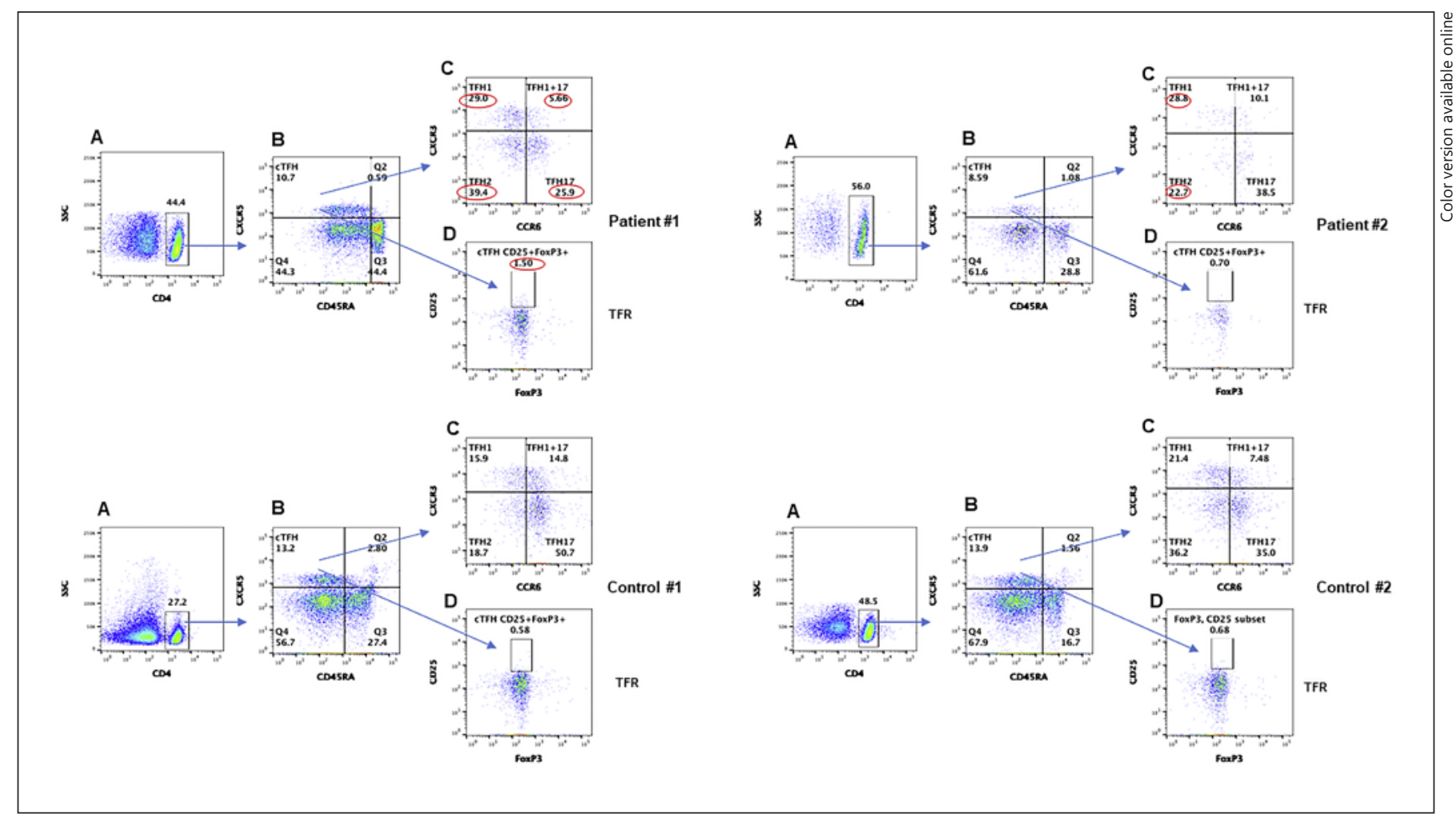

Fig. 3. $\mathrm{T}_{\mathrm{FH}}$ cell CD4+ gated cells in PBMCs $(\mathbf{A})$, gated CD4+ cells are characterized by different makers for $\mathrm{cT} \mathrm{T}_{\mathrm{FH}}$ expression CXCR5+CD45RA- (B). C $\mathrm{T}_{\mathrm{FH}}$ subsets $\mathrm{T}_{\mathrm{FH}} 1$ (CXCR3+CCR6-), $\mathrm{T}_{\mathrm{FH}} 1+\mathrm{T}_{\mathrm{FH}} 17(\mathrm{CXCR} 3+\mathrm{CCR} 6+), \mathrm{T}_{\mathrm{FH}} 2$ (CXCR3-CCR6), and $\mathrm{T}_{\mathrm{FH}} 17$ (CXCR3-CCR6+). D $\mathrm{T}_{\mathrm{FR}}$ cells (FoxP3+). Abnormal values are circled in red. PBMCs, peripheral blood mononuclear cells; $\mathrm{T}_{\mathrm{FH}}$, follicular helper $\mathrm{T} ; \mathrm{cT}_{\mathrm{FH}}$, circulating $\mathrm{T}_{\mathrm{FH}}$.

and CVID patient had contrasting changes in B cell subsets. The immunocompetent patient had increased naïve $B$ cells and decreased MZ, IgM memory, CSM, and $\mathrm{CD} 211^{\mathrm{ow}} \mathrm{B}$ cells. In contrast, the CVID patient had increased transitional, MZ, and IgM memory B cells but $\mathrm{CD} 21^{\text {low }} \mathrm{B}$ cells comparable to healthy control. Both patients had decreased GC B cells and plasmablasts. Breg were increased in both immunocompetent patient and CVID patient as compared to healthy controls.

Comparison of Changes in CD4+ and CD8+ T Cell Subsets and CD4+ Treg and CD8+ Treg between the Immunocompetent Patient and CVID Patient

To determine whether immunophenotypic changes were different among the immunocompetent patient and immunodeficiency (CVID) patient, we compared data of subsets of $\mathrm{CD} 4+, \mathrm{CD} 8+$, and $\mathrm{cT}_{\mathrm{FH}}$ cells among both patients. Among CD4+ T cells (Table 3), CD4+ and CD4+ $\mathrm{T}_{\mathrm{CM}}$ cells were decreased in the immunocompetent subject as compared to the CVID patient. Furthermore, $\mathrm{CD} 4+\mathrm{T}_{\mathrm{N}}, \mathrm{T}_{\mathrm{EM}}$, and $\mathrm{T}_{\mathrm{EMRA}}$, and CD4 Treg were increased in the immunocompetent subject as compared to the CVID patient. Among CD8+ T cells (Table 3), CD8+ T cells and $\mathrm{CD} 8+\mathrm{T}_{\mathrm{EM}}$ were comparable between both patients. However, $\mathrm{CD} 8+\mathrm{T}_{\mathrm{N}}$ cells were increased and CD8+ $\mathrm{T}_{\mathrm{EM}}, \mathrm{T}_{\mathrm{EMRA}}$, and CD8 Treg were decreased in the immunocompetent patient as compared to the CVID patient. Among $\mathrm{T}_{\mathrm{FH}}$ subsets (Table 3 ), $\mathrm{cT}_{\mathrm{FH}}$ and $\mathrm{T}_{\mathrm{FH}} 1$ were comparable among both patients. $\mathrm{T}_{\mathrm{FH}} 2$ and $\mathrm{T}_{\mathrm{FR}}$ cells were increased and $\mathrm{T}_{\mathrm{FH}} 17$ were decreased in the immunocompetent patient as compared to the CVID patient.

Changes in B Cell Subsets between the Immunocompetent Patient and CVID Patient

When data were analyzed for B cell and B cell subsets (Table 3), CD19+ GC B cells, plasmablasts, and CD21 ${ }^{\text {high }}$ mature $\mathrm{B}$ cells were comparable between both patients. Transitional, MZ, IgM memory, and CSM B cells were decreased in the immunocompetent patient as compared to the CVID patient. CD21 ${ }^{\text {low }}$ and Breg were increased in the CVID patient as compared to immunocompetent patient. 


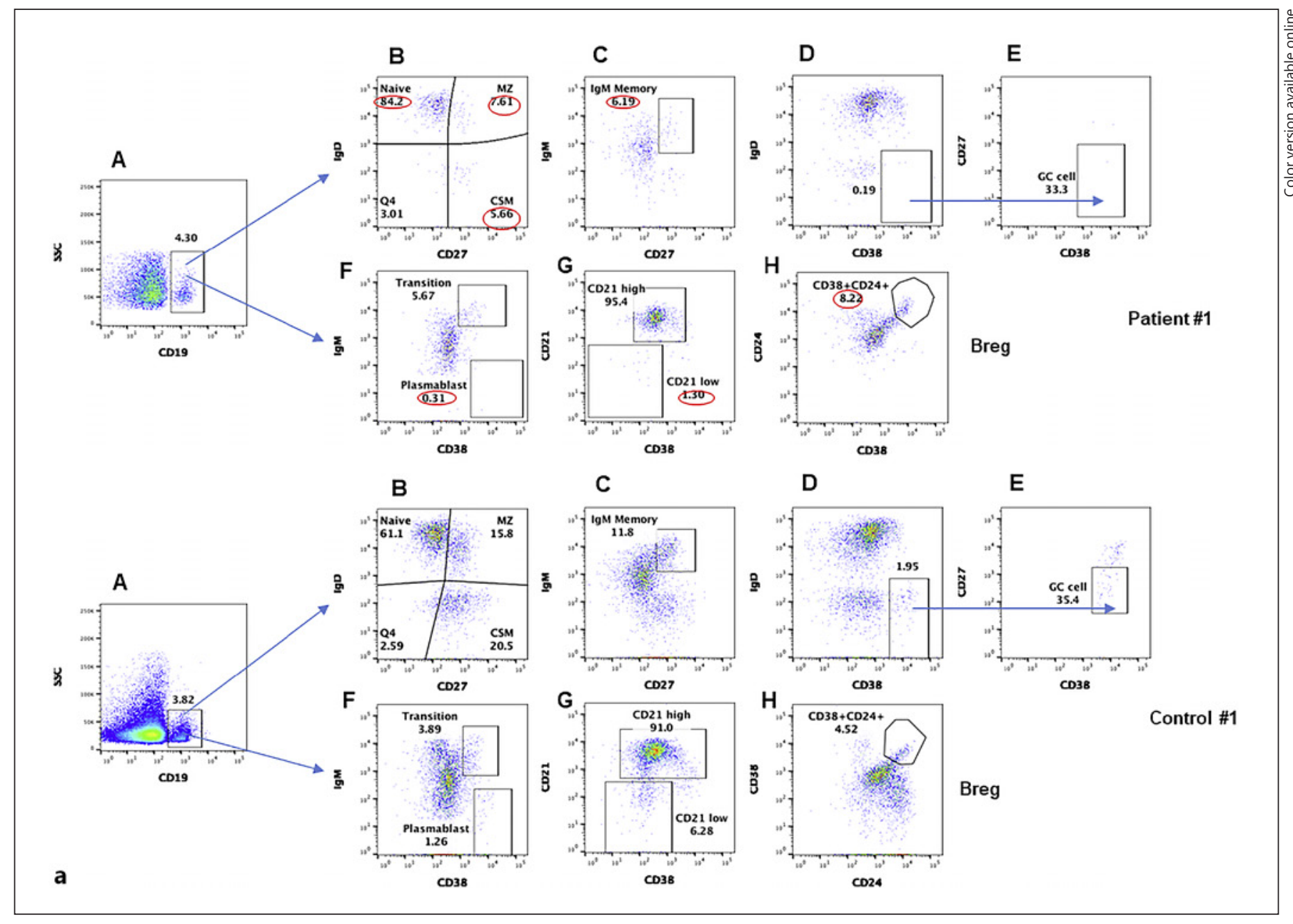

Fig. 4. a, b B cell subsets CD19+ gated cells in PBMCs (A), gated CD19+ cells subsets are characterized by different makers; naïve (IgD+CD27-) MZ (IgD+CD27+), CSM (IgD-CD27+) (B), IgM memory CD19+IgM+CD27+ (C), CD19+IgD-CD38+ (D), GC (CD19+IgD-CD38+CD27-) (E). Transitional B cells IgM+CD38+, plasmablasts IgM-CD38++ (F), mature B cells CD2 $1^{\text {high }}$ and CD2 $1^{\text {low }}$ cells $(\mathbf{G})$, Breg cells CD24+/CD38+ (H). Abnormal values are circled in red. PBMCs, peripheral blood mononuclear cells; GC, germinal center; $\mathrm{MZ}$, marginal zone; CSM, class-switch memory.

(Figure continued on next page.)

\section{Discussion}

Here we report distinct and often contrasting alterations in various lymphocyte subpopulations in a SARS-CoV-2+ immunocompetent patient and CVID patient with relatively mild disease that did not require hospitalization, oxygen supplementation, or any other specific treatment, and both were negative for anti-SARS-CoV-2 IgG antibodies. Our patients were different from those reported in the literature. First, both patients were SARS-CoV-2 antibody negative, and 1 patient has a diagnosis of primary antibody immunodeficiency, the CVID patient, and both patients had normal
$\mathrm{T}$ cell functions as demonstrated by normal proliferative response to mitogens and antigens (data not shown). The immunocompetent patient appears to have mild disease but continues to have some residual symptoms of cough and hoarseness, where the CVID patient has completely recovered. This is the first report of comprehensive analysis of various lymphocyte subpopulation in primary immunodeficiency disease.

Progressive lymphopenia is a common feature of COVID-19 that is often associated with severe disease [47, 48]. Our both patients with mild disease had normal absolute lymphocyte counts. 


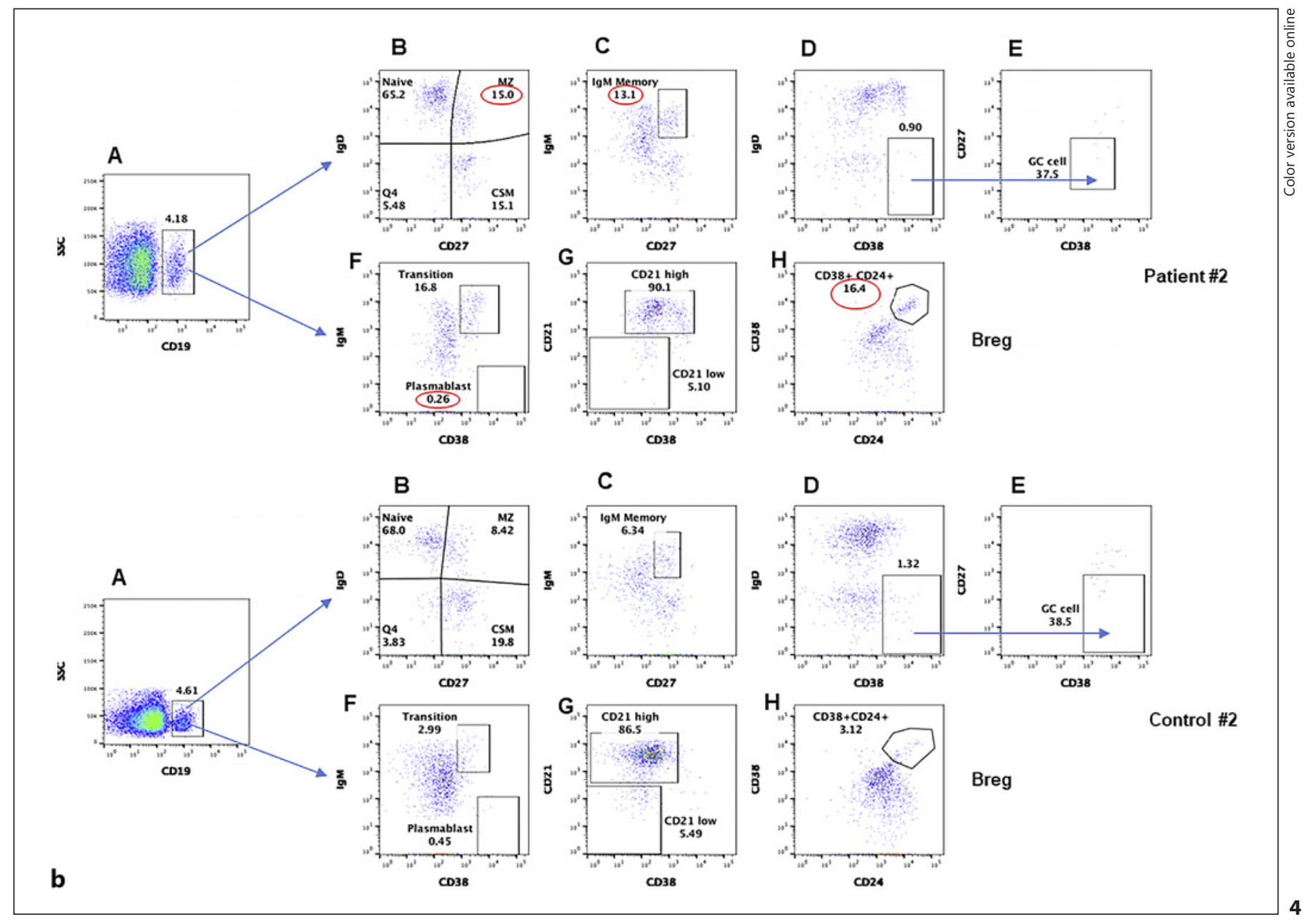

SARS-CoV-2-specific $\mathrm{T}$ cells have been identified in $\mathrm{T}_{\mathrm{CM}}, \mathrm{T}_{\mathrm{EM}}$, and $\mathrm{T}_{\mathrm{EMRA}}$ subsets [9]; however, their role in infection and pathogenesis has not been explored. There are limited studies of various subsets including naïve and memory subsets of CD4+ T cells and CD8+ T cells in COVID-19. Zang et al. [49] compared T cell subsets in severe and mild to moderate COVID-19 cases with healthy controls. They observed no difference in CD8 $+\mathrm{T}_{\mathrm{N}}$ cells among 3 groups; however, both groups of patients exhibited increased percentage of CD8 $+\mathrm{T}_{\mathrm{EM}}$ cells as compared to healthy controls. Furthermore, CD8 $+\mathrm{T}_{\mathrm{EMRA}}$ were higher in severe cases as compared to mild to moderate COVID-19 cases and healthy controls. Mathew et al. [31] also reported increased CD8+ $\mathrm{T}_{\mathrm{EMRA}}$; however, they observed decreased CD8 $+\mathrm{T}_{\mathrm{EM}}$ cells in recovered patients as compared to healthy controls. In our study, $\mathrm{CD} 8+\mathrm{T}_{\mathrm{EMRA}}$ cells were increased in CVID patient; however, they were decreased in the immunocompetent patient. These dif- ferences could be age related. $\mathrm{CD} 8+\mathrm{T}_{\mathrm{EMRA}}$ cells are increased with age $[24,26,28]$. Our CVID patient is 64 years old, whereas immunocompetent patient is 24 years old. Mathew et al. [31] and Zhang et al. [49] did not provide the ages of patients with increased CD8 $+\mathrm{T}_{\text {EMRA. The sig- }}$ nificance of increased CD8+ $\mathrm{T}_{\text {EMRA }}$ in COVID-19 remains unclear. Zhang et al. [49] observed increased in $\mathrm{CD} 8+\mathrm{T}_{\mathrm{EMRA}}$ in severe cases, whereas we observed increase in the CVID patient who had a mild course of COVID-19. Similar to Mathew et al. [31], both our patients had decreased CD8+ $\mathrm{T}_{\mathrm{EM}}$ cells. In contrast to Zhang et al. [49] who observed no changes in CD8+ $\mathrm{T}_{\mathrm{N}}$ cells, our immunocompetent COVID-19 patient had increased CD8+ $\mathrm{T}_{\mathrm{N}}$ cells.

Mathew et al. [31] reported decreased CD4+ $\mathrm{T}_{\mathrm{N}}$ and increased $\mathrm{CD} 4+\mathrm{T}_{\mathrm{EMRA}}$ recovered patients as compared to healthy controls. Zhang et al. [49] also observed increased $\mathrm{CD} 4+\mathrm{T}_{\mathrm{EMRA}}$ cells; however, no changes were ob- 
Table 3. Comparison of lymphocyte subsets between 2 patients

\begin{tabular}{|c|c|c|c|c|c|c|c|c|c|c|c|}
\hline & $\mathrm{CD} 4+$ & $\mathrm{T}_{\mathrm{N}}$ & $\mathrm{T}_{\mathrm{CM}}$ & $\mathrm{T}_{\mathrm{EM}}$ & $\mathrm{T}_{\text {EMRA }}$ & $\begin{array}{l}\text { CD25 } 5^{\text {high }} \text { CD127- } \\
\text { FoxP3+ (CD4 Treg) }\end{array}$ & & & & & \\
\hline \multicolumn{12}{|c|}{ a Subpopulations of CD4+ T cells } \\
\hline \multirow[t]{2}{*}{ Patient \#2 } & 57.70 & 25.80 & 64.20 & 9.76 & 0.16 & 2.12 & & & & & \\
\hline & CD8+ & $\mathrm{TN}$ & TCM & TEM & TEMRA & \multicolumn{6}{|l|}{$\begin{array}{l}\text { CCR7+CD45RA- } \\
\text { CXCR3+ (CD8 Treg) }\end{array}$} \\
\hline \multicolumn{12}{|c|}{ b Subpopulations of CD8+ T cells } \\
\hline Patient \#1 & 26.40 & 48.70 & 5.39 & 26.40 & 19.50 & 0.04 & & & & & \\
\hline \multirow[t]{2}{*}{ Patient \#2 } & 24.00 & 18.60 & 15.80 & 25.00 & 40.50 & 0.10 & & & & & \\
\hline & $\mathrm{CD} 4+$ & cTFH & TFH1 & TFH2 & TFH17 & TFH1/TFH17 & $\begin{array}{l}\text { CCR5+ } \\
\text { CD25highFoxP3+ (TFR) }\end{array}$ & & & & \\
\hline Patient \#2 & CD19+ & Naive & Transition & $\mathrm{MZ}$ & IgM mem & CSM & GC & Plasmablast & $\mathrm{CD} 21+$ & CD21Low & B Reg \\
\hline \multicolumn{12}{|c|}{ d Subpopulations of B cells } \\
\hline Patient \#1 & 4.30 & 84.20 & 5.67 & 7.61 & 6.19 & 5.66 & 0.00 & 0.31 & 95.40 & 1.30 & 8.22 \\
\hline Patient \#2 & 4.18 & 65.20 & 16.80 & 15.00 & 13.10 & 15.10 & 0.01 & 0.26 & 90.10 & 5.10 & 16.40 \\
\hline
\end{tabular}

$\mathrm{T}_{\mathrm{FH}}$, follicular helper $\mathrm{T} ; \mathrm{T}_{\mathrm{N}}$, T naïve; $\mathrm{T}_{\mathrm{EM}}$, $\mathrm{T}$ effector memory; $\mathrm{T}_{\mathrm{CM}}, \mathrm{T}$ central memory; $\mathrm{T}_{\mathrm{EMRA}}, \mathrm{T}$ effector memory RA; $\mathrm{T}_{\mathrm{FH}}$, follicular helper $\mathrm{T} ; \mathrm{GC}$, germinal center; MZ, marginal zone; CSM, class-switch memory.

served in CD4 $+\mathrm{T}_{\mathrm{N}}$ cells. Our immunocompetent patient also had increased CD4+ $\mathrm{T}_{\mathrm{EMRA}}$ as well as $\mathrm{CD} 4+\mathrm{T}_{\mathrm{N}}$ and decreased $\mathrm{CD} 4+\mathrm{T}_{\mathrm{EM}}$ cells. In contrast, all subsets of CD4+ T cells in CVID patients were comparable to healthy controls.

$\mathrm{T}_{\mathrm{FH}}$ cells are major CD4+ Thelper subsets that are essential for B-cell differentiation into immunoglobulinproducing plasma cells, and for GC formation and generation of memory B cells [39-44]. GC is the primary site for class-switched DNA recombination and affinity maturation. $\mathrm{T}_{\mathrm{FH}}$ cells in the GC regulate class-switched DNA recombination, and selection of high-affinity antibodyproducing $\mathrm{B}$ cells. $\mathrm{T}_{\mathrm{FH}}$ cells are characterized by the expression of CXCR5 and transcription factor B-cell lymphoma 6 , and production of their signature cytokine, the interleukin 21 (IL-21). According to the expression of CXCR3 and CCR6 on CD4+CXCR5+ $\mathrm{CT}_{\mathrm{FH}}$ cells, they are divided into 3 different subsets of $\mathrm{cT}_{\mathrm{FH}}$ cells with different functions [45]. In addition to IL-21, these different $\mathrm{cT}_{\mathrm{FH}}$ subsets can also produce, albeit in lower amounts, IL-4, interferon $\gamma$, and IL-17. $\mathrm{cT}_{\mathrm{FH}} 1\left(\mathrm{CXCR}^{+} \mathrm{CXCR}^{+}{ }^{+} \mathrm{CCR} 6^{-}\right)$ produce IL-21 and interferon $\gamma, \mathrm{cT}_{\mathrm{FH}} 2$ $\left(\mathrm{CXCR}^{+}{ }^{+} \mathrm{CXCR}^{-}{ }^{-} \mathrm{CCR}^{-}{ }^{-}\right.$) produce IL-21 and IL-4, and $\mathrm{CT}_{\mathrm{FH}} 17\left(\mathrm{CXCR}^{+}{ }^{+} \mathrm{CXCR}^{-}{ }^{-} \mathrm{CCR} 6^{+}\right)$produce IL-21 and IL$17 \mathrm{~A}$; all of them are able to efficiently induce antibody response by memory $\mathrm{B}$ cells. $\mathrm{T}_{\mathrm{FH}} 17$ cells are able to induce in vitro naïve and memory $B$ cells to produce IgG and $\operatorname{Ig} \mathrm{A}$, and their increase is associated with expansion of plasmablasts [50]. In our immunocompetent patient, $\mathrm{cT}_{\mathrm{FH}} 17$ cells were decreased as compared to control, which would be consistent with decreased plasmablasts and negative anti-SARS-CoV-2 antibodies. In the CVID patient, $\mathrm{cT}_{\mathrm{FH}} 17$ cells were similar to control. In the CVID patient, decreased plasmablasts and negative anti-SARSCoV-2 antibodies may be due to intrinsic B-cell defect.

Thevarajan et al. [32] examined $\mathrm{cT}_{\mathrm{FH}}$ and antibodysecreting cells/plasmablasts in a patient with non-severe COVID-19 prior to symptomatic recovery. They observed the appearance of plasmablasts and $\mathrm{cT}_{\mathrm{FH}}$ cells at 7 days, peaking at day 8 , and were present during convalescence. These changes were associated with the development of IgM and IgG anti-SARS-CoV-2 antibodies. They 
proposed that $\mathrm{cT}_{\mathrm{FH}}$ cells and/or plasmablasts could be used as predictors or play a major role in determining severity of COVID-19. However, this appears to be an unlikely predictor since both our patients with mild disease had decreased or complete absence of plasmablasts and GC cells and decreased $\mathrm{cT}_{\mathrm{FH}}$ with negative SARS-CoV-2 antibodies. Kasahara et al. [51] reported no changes in the proportions and functions of $\mathrm{cT}_{\mathrm{FH}}$ and proportions of ICOS+PD-1+ $\mathrm{cT}_{\mathrm{FH}}$ in CVID patients. Therefore, decreased $\mathrm{cT}_{\mathrm{FH}}$ in our patient with CVID is likely the effect of SARS-CoV-2 infection. Mathew et al. [31] observed increased activated (ICOS+) $\mathrm{T}_{\mathrm{FH}}$ cells but observed no difference in PD1 $+\mathrm{T}_{\mathrm{FH}}$ cells in COVID-19 patients. Several investigators have reported increased $\mathrm{T}_{\mathrm{FH}} 1$ in CVID $[51,52]$. In both CVID patient and immunocompetent patient, $\mathrm{T}_{\mathrm{FH}} 1$ cells were increased, therefore suggesting skewing of $\mathrm{cT}_{\mathrm{FH}}$ toward $\mathrm{T}_{\mathrm{FH}} 1$ that is a feature of $\mathrm{CO}$ VID-19.

There are very few reports of comprehensive analysis of B cell subsets in COVID-19 and none in SARS-CoV-2+ primary immunodeficiency. Woodruff et al. [53] reported dominant extrafollicular B cell responses in severe COVID-19 disease that correlated with increased specific antibody production but poor clinical outcome. Several investigators have reported increased number and activation of $\mathrm{B}$ cells and increased antibody production in severe COVID-19 cases [54-56]. Mathew et al. [31] reported decreased naïve and CSM B cells and increased nonclass-switched IgM memory B cells and antibody-secreting cells (plasmablasts) in recovered patients as compared to healthy controls. In our patients, CD19+ B cells were comparable in both patients as compared to healthy controls, and in contrast to Mathew et al. [31], plasmablasts were decreased in both patients with negative antibodies. Therefore, it appears that changes in $\mathrm{B}$ cells do not necessarily correlate with severity of disease or increased specific antibody production. In addition, GC B cells were reduced. Kaneko et al. [57] also reported absence of GCs and marked reduction in B-cell lymphoma 6+ GC B cells in postmortem thoracic duct lymph nodes and spleen from COVID-19 patients; however, they did not provide patients' antibody status. In our immunocompetent patient, MZ B cells, IgM memory B cells, CSM B cells, and CD21 ${ }^{\text {low }} \mathrm{B}$ cells were decreased as compared to age-matched control. In contrast, the CVID patient had increased transitional zone, MZ, and IgM memory B cells, but CSM B cells were decreased. Mathew et al. [31] did not examine GC B cells or MZ B cells; however, they also observed increased transitional B cells. Kaneko et al. [57] did not report transitional B cells and MZ B cells. CD21 forms a complex with CD19 and CD81 to act as a $\mathrm{B}$ cell co-receptor. This population of $\mathrm{B}$ cell is distinct from other $B$ cell subpopulation that resembles innatelike B cells [58]. CD21 low $B$ cells are increased in CVID patients with autoimmunity [59]. Our immunocompetent subject had reduced proportions of $\mathrm{CD} 21^{\text {low }} \mathrm{B}$ cells, in contrast to increased CD2 $1^{\text {low }} \mathrm{B}$ cells in mild cases of COVID-19 reported by Woodruff et al. [60].

Regulatory lymphocytes play a critical role in immune homeostasis and immunological tolerance. There are several members of immunoregulatory club including CD4+ Treg, CD8+ Treg, B reg, and $\mathrm{T}_{\mathrm{FR}}$ cells. CD4+ Treg and CD8+ Treg were originally described in 1982 [61]. Sakaguchi and his group further characterized CD4+ Treg by the expression of CD25 and FoxP3 [62]. The role of CD4+ Treg in immune tolerance is well established [63]. In both patients, CD4+ Treg were comparable to healthy controls. This is in agreement with observations of Zhang et al. [49], who did not find any difference in CD4+ Treg between mild, severe cases, and healthy controls; however, this is in contrast to Qin et al. [64], who reported decreased CD4+ Treg in severe cases of COVID-19.

Recent interest in CD8+ Treg lead to their phenotypic and functional characterization [65-67]. CD8+ Treg have shown to play an important role in immune homeostasis, including inhibition of B-cell proliferation and differentiation of B cells into immunoglobulin-secreting plasmablasts $[67,68]$. Since both our patients continued to be SARS-CoV-2 antibodies negative, we examined CD8+ Treg. CD8+ Treg in both patients were comparable to healthy controls. Therefore, CD8+ Treg appear not to play a role in SARS-CoV-2 antibody responses in our patients. The negative SARS-CoV-2 antibodies in CVID patient are likely due to intrinsic $\mathrm{B}$ cell defect. There are no published data on CD8+ Treg in COVID-19.

$\mathrm{T}_{\mathrm{FR}}$ cells regulate the differentiation of $\mathrm{cT}_{\mathrm{FH}}$ cells [46]. Our immunocompetent patient had increased $\mathrm{T}_{\mathrm{FR}}$; however, $\mathrm{cT}_{\mathrm{FH}}$ cells were comparable to healthy control. In contrast, the CVID patient had decreased $\mathrm{cT}_{\mathrm{FH}}$ cells but $\mathrm{T}_{\mathrm{FR}}$ were comparable to control. Furthermore, Cunill et al. [69] reported decreased $\mathrm{T}_{\mathrm{FR}}$ cells in CVID patients with $<2 \% \mathrm{CD} 27+\operatorname{IgD}-\mathrm{B}$ cells. Therefore, significance of increased $\mathrm{T}_{\mathrm{FR}}$ in immunocompetent patient remain unclear.

There has been increasing interest in understanding the role and mechanism of Breg [70-74]. Breg regulate immune responses including inflammatory responses in a variety of autoimmune diseases [72] and regulate the generation of peripheral CD4+ Treg cells $[75,76]$. Both patients had increased Breg cells. No relationship was observed with $\mathrm{CD} 4+\mathrm{Reg}$. There are no published data on 
Breg in COVID-19. It remains to be determined if increased Breg play a role in decreased plasmablasts and negative anti-SARS-CoV-2 antibodies.

When alterations in various lymphoid subpopulations were compared between 2 patients, the immunocompetent patient demonstrated greater and often contrasting changes as compared to the CVID patient. Subsets of $\mathrm{CD} 4+\mathrm{T}$ cells and $\mathrm{B}$ cells revealed greater changes than in subpopulations of CD8+ T cells, which would be consistent with negative antibody responses.

Neutralizing antibodies inhibit SARS-CoV-2 both in vitro and in vivo [77, 78]. Chen et al. [79] observed that patients recovered from severe illness mounted the most robust neutralizing antibody responses. They have demonstrated a positive correlation between the magnitude of neutralizing antibody responses and disease severity in patients recovered from COVID-19. These investigators also reported that asymptomatic patients fail to generate neutralizing antibodies. Our immunocompetent patient was 24 years young with mild disease and had undetectable anti-SARS-CoV-2 antibodies. The CVID patient was also negative for SARS-CoV-2 antibodies yet had mild course. COVID-19 disease has been reported in patients with primary immunodeficiency; however, no comprehensive immunological analyses have been published [80, 81]. Myets et al. [82], in an international study, reported that the majority of COVID-19 patients in primary immunodeficiency were X-linked agammaglobulinemia (no B cells) and CVID and had either mild to moderate disease severity or recovered completely. There were no deaths in those without high-risk morbidity factors. Quinti et al. [80] reported 7 COVID-19 patients with antibody deficiency ( 2 with agammaglobulinemia and 5 with CVID). Interestingly, patients with agammaglobulinemia had mild course of the disease and recovered, whereas patients with CVID presented with a severe form of disease and required multiple drugs including antiviral agents. Since a subset of CVID patients also have T-cell defects, it is possible that severe disease in few CVID patients was related to T-cell dysfunctions. Soresina et al. [81] also reported 2 patients with X-linked agammaglobulinemia (no B cells) with COVID-19 who developed pneumonia; however, they did not require oxygen ventilation or admission to intensive care and both patients recovered. In patients with antibody deficiency diseases, mild disease and complete recovery could be because of lack of cytokine storm response and/or lack of antibodies-dependent enhancement (ADE) of SARS-CoV-2 infection [83]. Similarly, a role of ADE could be made in severe COVID-19 patients with high titers of antibodies and poor clinical outcome.
However, there is no evidence of SARS-CoV-2 ADE. Quinlan et al. [84] reported that sera from rats vaccinated with SARS-CoV-2 RBD in vitro failed to demonstrate any ADE of SARS-CoV-2. Gao et al. [85] reported failure to ADE in macaques immunized with an inactivated SARSCoV-2 vaccine candidate. Furthermore, there are conflicting data for the beneficial effect of convalescent plasma transfusion on the clinical course of COVID-19; both beneficial effect [86] as well as lack of beneficial effects have been observed [87]. Li et al. [87] reported that among patients with severe or life-threatening COVID-19, convalescent plasma therapy added to standard treatment, compared with standard treatment alone, did not result in a statistically significant improvement in time to clinical improvement within 28 days. Therefore, mild to moderately severe disease in patients with X-linked agammaglobulinemia with complete absence of B cells and specific antibody response as well in our patients with negative anti-SARS-CoV-2 antibodies strongly suggest an important role of T cells in SARS-CoV-2 infection.

In summary, our patient with primary immunodeficiency disease (CVID) and the immunocompetent patient demonstrate different changes in cells of the immune system during SARS-CoV-2 infection. It is unknown as to the protective immunity that prevents asymptomatic patients from progressing to more severe disease. Failure to produce anti-SARS-CoV-2 antibodies yet a mild to moderate clinical course strongly suggests a critical role of $\mathrm{T}$ cells in defense against SARS-CoV-2. Patients with primary immunodeficiency diseases are "experiments of nature" and because of specific gene mutations provide unique opportunities to study protective immune responses to SARS-CoV-2. Changes in subsets of various lymphocytes in the COVID-19 CVID patient were different than those observed in CVID patients without SARS-CoV-2 infection, suggesting that those alterations are most likely due to SARS-CoV-2 infection. Our study also highlights that alteration in lymphocyte subsets persist long after SARS-CoV-2 infection. Studies of both phenotypic and functional changes in large cohort of patients with primary immunodeficiency with defined gene mutations SARS-CoV-2 infection are needed.

\section{Statement of Ethics}

The investigation was carried out following the rules of the Declaration of Helsinki of 1975 revised in 2013. Institutional Review Board (human subject committee), University of California in Irvine approved the protocol (HS\# 2001-1). Each and all subjects gave written consent. 


\section{Conflict of Interest Statement}

None of the authors declare any conflict of interest.

\section{Funding Sources}

This work was supported by unrestricted funds from the Division of Basic and Clinical Immunology, University of California, Irvine.

\section{References}

1 Huang C, Wang Y, Li X, Ren L, Zhao J, Hu Y, et al. Clinical features of patients infected with 2019 novel coronavirus in Wuhan, China. Lancet. 2020;395(10223):497-506.

2 Wang J, Jiang M, Chen X, Montaner LJ. Cytokine storm and leukocyte changes in mild versus severe SARS-CoV-2 infection: review of 3939 COVID-19 patients in China and emerging pathogenesis and therapy concepts. J Leukoc Biol. 2020 Jul;108(1):17-41.

3 Zhou Y, Fu B, Zheng X, Wang D, Zhao C, Qi $\mathrm{Y}$, et al. Pathogenic T-cells and inflammatory monocytes incite inflammatory storms in severe COVID-19 patients. Natl Sci Rev. 2020; 7(6):998-1002.

4 Chen Z, John Wherry E. T cell responses in patients with Covid-19. Nat Rev Immunol. 2020;20(9):529-36.

5 Kuri-Cervantes L, Pampena MB, Meng W, Rosenfeld AM, IttnerWeisman CAGAR, Weisman AR, et al. Comprehensive mapping of immune perturbations associated with severe COVID-19. Sci Immunol. 2020 Jul 15; 5(49):eabd7114.

6 Giamarellos-Bourboulis EJ, Netea MG, Rovina N, Akinosoglou K, Antoniadou A, Antonakos $\mathrm{N}$, et al. Complex immune dysregulation in COVID-19 patients with severe respiratory failure. Cell Host Microbe. 2020;27(6):9921003.e3.

7 Wilk AJ, Rustagi A, Zhao NQ, Roque J, Martínez-Colón GJ, McKechnie JL, et al. A singlecell atlas of the peripheral immune response in patients with severe COVID-19. Nat Med. 2020;26(7):1070-6.

8 Diao B, Wang C, Tan Y, Chen X, Liu Y, Ning $\mathrm{L}$, et al. Reduction and functional exhaustion of $\mathrm{T}$ cells in patients with coronavirus disease 2019 (COVID-19). Front Immunol. 2020;11: 827.

9 Weiskopf D, Schmitz KS, Raadsen MP, Grifoni A, Okba NMA, Endeman H, et al. Phenotype and kinetics of SARS-CoV-2-specific T cells in COVID-19 patients with acute respiratory distress syndrome. Sci Immunol. 2020; 5(48):eabd2071.

10 Endeman G, Wu D, Guo W, Cao Y, Huang D, Wang $\mathrm{H}$, et al. Clinical and immunological features of severe and moderate coronavirus disease 2019. J Clin Invest. 2020;130(5):26209.

Subsets of CD4, CD8 T Cells, B Cells, and Regulatory Lymphocytes in COVID-19

\section{Author Contributions}

T.N. collected clinical data and followed case 1. H.S. performed flow cytometry. S.A. analyzed flow cytometry data. S.G. supervised HS and wrote the manuscript.
11 Mazzoni A, Salvati L, Maggi L, Capone M, Vanni A, Spinicci M, et al. Impaired immune cell cytotoxicity in severe COVID-19 is IL-6 dependent. J Clin Invest. 2020;130(9):4694703.

12 Zheng HY, Zhang M, Yang CX, Zhang N, Wang XC, Yang XP, et al. Elevated exhaustion levels and reduced functional diversity of $\mathrm{T}$ cells in peripheral blood may predict severe progression in COVID-19 patients. Cell Mol Immunol. 2020;17(5):541-3.

13 Wen W, Su W, Tang H, Le W, Zhang X, Zheng $\mathrm{Y}$, et al. Immune cell profiling of COVID-19 patients in the recovery stage by single-cell sequencing. Cell Discov. 2020;6(6):31.

14 Ni L, Ye F, Cheng ML, Feng Y, Deng YQ, Zhao H, et al. Detection of SARS-CoV-2-specific humoral and cellular immunity in COVID-19 convalescent individuals. Immunity. 2020;52(6):971-77.e3.

15 Dong T, Mentzer AJ, Liu G, Yao X, Yin Z, Dong $\mathrm{D}$, et al. Broad and strong memory CD4 and CD8 $\mathrm{T}$ cells induced by SARS-CoV- 2 in UK convalescent COVID-19 patients. bioRxiv. 2020 Jun 8.

16 Siracusano G, Pastori C, Lopalco L. Humoral immune responses in Covid-19 patients. A window on the State of the Art. Front Immunol. 2020 May; 11:1049.

17 Qin C, Zhou L, Hu Z, Zhang S, Yang S, Tao Y, et al. Dysregulation of immune response in patients with coronavirus 2019 (COVID-19) in Wuhan, China. Clin Infect Dis. 2020 Jul 48; 71(15):762-8

18 Sallusto F, Lenig D, Förster R, Lipp M, Lanzavecchia $A$. Two subsets of memory T lymphocytes with distinct homing potentials and effector functions. Nature. 1999;401(6754): 708-12.

19 Masopust D, Vezys V, Marzo AL, Lefrançois L. Preferential localization of effector memory cells in nonlymphoid tissue. Science. 2001; 291(5512):2413-7.

20 Weninger W, Crowley MA, Manjunath N, von Andriane UH. Migratory properties of naïve, effector, and memory CD8(+) T cells. J Exp Med. 2001;194:953-66.

21 Tomiyama H, Matsuda T, Takiguchi M. Differentiation of human CD8(+) T cells from a memory to memory/effector phenotype. J Immunol. 2002;168(11):5538-50.
22 Geginat J, Lanzavecchia A, Sallusto F. Proliferation and differentiation potential of human CD8+ memory T-cell subsets in response to antigen or homeostatic cytokines. Blood. 2003;101(11):4260-6.

23 Van Lier RA, ten Berge IJ, Gamadia LE. Human CD8(+) T-cell differentiation in response to viruses. Nat Rev Immunol. 2003; 3(12):931-9.

24 Gupta S, Bi R, Su K, Yel L, Chiplunkar S, Gollapudi S. Characterization of naïve/memory effector subsets of CD8+ T cells: changes in aged humans. Exp Gerontology. 2004;20: 545-50.

25 Gupta S, Gollapudi S. Molecular mechanisms of TNF-alpha-induced apoptosis in naïve and memory $\mathrm{T}$ cell subsets. Autoimmun Rev. 2006;5(4):264-8.

26 Gupta S. Molecular mechanisms of TNF- $\alpha$ induced apoptosis in naïve and memory T cell subsets: effect of age. Immunol Rev. 2005;205: $114-25$

27 Gupta S. Molecular mechanisms of TNF- $\alpha$ induced apoptosis in naïve and memory T cell subsets: effect of age. Immunol Rev. 2005;205: $114-25$.

28 Gupta S, Su H, Bi R, Gollapudi S. Differential sensitivity of naïve and memory subsets of human CD8+ T cells to TNF- $\alpha$-induced apoptosis. J Clin Immunol. 2006;26(3):193-203.

29 Gupta S, Bi R, Gollapudi S. Central memory and effector memory subsets of human CD4(+) and CD8(+) T cells display differential sensitivity to TNF-\{alpha\}-induced apoptosis. Ann N Y Acad Sci. 2005; 1050:108-14.

30 Jiang S, Hillyer C, Du L. Neutralizing antibodies against SARS-CoV-2 and other human coronaviruses: (Trends in Immunology 41, 355-359; 2020). Trends Immunol. 2020 Jun; 41(6):545-9.

31 Mathew D, Giles JR, Baxter AE, Greenplate $\mathrm{AR}, \mathrm{Wu}$ JE, Alanio C, et al. Deep immune profiling of COVID-19 patients reveals patient heterogeneity and distinct immunotypes with implications for therapeutic interventions. bioRxiv [Preprint]. 2020 May 23.

32 Thevarajan I, Nguyen THO, Koutsakos M, Druce J, Caly L, van de Sandt CE, et al. Breadth of concomitant immune responses prior to patient recovery: a case report of non-severe COVID-19. Nat Med. 2020;26:453-5. 
33 Wen W, Su W, Tang H, Le W, Zhang X, Zheng $\mathrm{Y}$, et al. Immune cell profiling of COVID-19 patients in the recovery stage by single-cell sequencing. Cell Discov. 2020;6:31.

34 LeBien TW, Tedder TF. B lymphocytes: how they develop and function. Blood. 2008 Sep; 112(5):1570-80.

35 Kurosaki T. B-lymphocyte biology. Immunol Rev. 2010 Sep;237(1):5-9.

36 Pieper K, Grimbacher B, Eibel H. B-cell biology and development. J Allergy Clin Immunol. 2013 Apr;131(4):959-71.

37 Martin F, Kearney JF. Marginal-zone B cells. Nat Rev Immunol. 2002;2(5):323-35.

38 Seifert M, Przekopowitz M, Taudien S, Lollies A, Ronge V, Drees B, et al. Functional capacities of human IgM memory B cells in early inflammatory responses and secondary germinal center reactions. Proc Natl Acad Sci U S A. 2015 Feb;112(6):E546-55.

39 Crotty S. Follicular helper CD4 T cells (TFH). Annu Rev Immunol. 2011;29:621-63.

40 Uneo H. Human circulating T follicular helper cell subsets in health and disease. J Clin Immunol. 2016;36(Suppl 1):34-9.

41 Victora GD, Schwickert TA, Fooksman DR, Kamphorst AO, Meyer-Hermann M, Dustin ML, et al. Germinal center dynamics revealed by multiphoton microscopy with a photoactivatable fluorescent reporter. Cell. 2010; 143(4):592-605.

42 Crotty S. T follicular helper cell biology: a decade of discovery and diseases. Immunity. 2019;50(5):1132-48.

43 Schmitt N, Bentebibel SE, Ueno H. Phenotype and functions of memory Tfh cells in human blood. Trends Immunol. 2014;35(9):436-42.

44 Schaerli P, Willimann K, Lang AB, Lipp M, Loetscher P, Moser B. CXC chemokine receptor 5 expression defines follicular homing $\mathrm{T}$ cells with B cell helper function. J Exp Med. 2000;192(11):1553-62.

45 Morita R, Schmitt N, Bentebibel SE, Ranganathan R, Bourdery L, Zurawski G, et al. Human blood CXCR5(+)CD4(+) T cells are counterparts of $\mathrm{T}$ follicular cells and contain specific subsets that differentially support antibody secretion. Immunity. 2011;34(1):108-21.

46 Zhu Y, Zou L, Liu YC. T follicular helper cells, $\mathrm{T}$ follicular regulatory cells and autoimmunity. Int Immunol. 2016;28(4):173-9.

47 Guan WJ, Ni ZY, Hu Y, Liang WH, Ou CQ, $\mathrm{He} J \mathrm{X}$, et al. Clinical characterstics of coronavirus disease 2019 in China. N Engl J Med. 2020;382:1708-20.

48 Tan L, Wang Q, Zhang D, Ding J, Huang Q, Tang YQ, et al. Lymphopenia predicts disease severity of COVID-19: a descriptive and predictive study. Signal Transduct Target Ther. 2020;5(1):33.

49 Zhang F, Gan R, Zhen Z, Hu X, Li X, Zhou F, et al. Adaptive immune responses to SARS $\mathrm{CoV}-2$ infections in severe versus mild individuals. Signal Transduct Target Ther. 2020; 156:5.
50 Li XY, Wu ZB, Ding J, Zheng ZH, Li XY, Chen $\mathrm{LN}$, et al. Role of the frequency of blood CD4(+) CXCR5(+) CCR6(+) T cells in autoimmunity in patients with Sjögren's syndrome. Biochem Biophys Res Commun. 2012;422(2):238-44.

51 Kasahara T, de M, Bento CAM, Gupta S. Phenotypic and functional analysis of T-follicular cells in common variable immunodeficiency. Int Arch Allergy Immunol. 2020;181(8):63547.

52 Turpin D, Furudoi A, Parrens M, Blanco P, Viallard J-F, Duluc D. Increase of follicular helper T cells skewed toward a Th1 profile in CVID patients with non-infectious clinical complications. Clinical Immunol. 2018;197: $130-8$.

53 Woodruff MC, Ramonell RP, Cashman KS, Nguyen DC, Saini AS, Haddad N, et al. Dominant extrafollicular B cell responses in severe Covid-19 disease correlate with robust viralspecific antibody production but poor clinical outcome. medRxiv. 2020 Ma 3.

54 Zhang B, Zhou X, Zhu C, Feng F, Qiu Y, Feng $\mathrm{J}$, et al. Immune phenotyping based on neutrophil-to-lymphocyte ratio and IgG predicts disease severity and outcome for patients with COVID-19. 2020.

55 Zhao J, Yuan Q, Wang H, Liu W, Liao X, Su $\mathrm{Y}$, et al. Antibody responses to SARS-CoV-2 in patients of novel coronavirus disease 2019. Clin Infect Dis. 2020 Nov;71:2027-34.

56 Long Q-X, Liu B-Z, Deng H-J, Gui-Cheng Wu G-C, Deng K, Chen Y-K, et al. Antibody responses to SARS-CoV-2 in patients with COVID-19. Nat Med. 2020;26:845-8.

57 Kaneko N, Kuo H-H, Boucau J, Farmer JR, Allard-Chamard H, Mahajan VS, et al. Loss of Bcl-6 expressing T follicular helper cells, and germinal centers in Covid-19. Cell. 2020;183: $1-15$.

58 Rakhmanov M, Keller B, Gutenberger S, Foerster C, Hoenig M, Driessen G, et al. Circulating CD21low $\mathrm{B}$ cells in common variable immunodeficiency resemble tissue homing, innate-like B cells. Proc Natl Acad Sci U S A. 2009;106:13451-6.

59 Arumugakani G, Wood PM, Carter CR. Frequency of Treg cells is reduced in CVID patients with autoimmunity and splenomegaly and is associated with expanded CD21lo B lymphocytes. J Clin Immunol. 2010;30:292300.

60 Woodruff MC, Ramonell RP, Ckasman KS, Nguyen DC, Sain AS, Haddad N, et al. Dominant extrafollicular B cell responses in severe Covid-19 disease correlates with robust viralspecific antibody production but poor clinical outcomes. MedRxiV. 2020.04.29.20083717.

61 Damle NK, Gupta S. Heterogeneity of concanavalin A-induced suppressor $\mathrm{T}$ cells in man defined with monoclonal antibodies. Clin Exp Immunol. 1982;48:581-8.

62 Sakaguchi S, Miyara M, Costantino CM, Haf ler DA. FOXP3+ regulatory T cells in the human immune system. Nat Rev Immunol [Internet]. 2010;10(7):490-500.
63 Safinia N, Scotta C, Vaikunthanathan T, Lechler RI, Lombardi G. Regulatory T cells: serious contenders in the promise for immunological tolerance in transplantation. Front Immunol. 2015;6:438.

64 Qin C, Zhou L, Hu Z, Zhang S, Yang S, Tao Y et al. Dysregulation of immune response in patients with coronavirus 2019 (COVID-19) in Wuhan, China. Clin infect dis. 2020;71: 762-8.

65 Rifa' IM, Kawamoto Y, Nakashima I, Suzuki $\mathrm{H}$. Essential roles of CD8+CD122+ regulatory $\mathrm{T}$ cells in maintenance of $\mathrm{T}$ cell homeostasis. J Exp Med. 2004;200:1123-34.

66 Flippe L, Bézie S, Anegon I, Guillonneau C. Future prospects for CD8+ regulatory $\mathrm{T}$ cells in immune tolerance. Immunol Rev. 2019 Nov;292(1):209-24.

67 Gupta S, Su H, Agrawal S. CD8 treg cells inhibit $B$ cell proliferation and immunoglobulin production. Int Arch Allergy Immunol. 2020; 181(12):947-55.

68 Gupta S, Agrawal S. In vitro effects of CD8 Treg on human B cell subpopulations. Int Arch Allergy Immunol. 2020;181:476-80

69 Cunill V, Clemente A, Lanio N, Barceló C, Andreu V, Pons J, et al. Follicular T cells from smB. Front Immunol. 2017;8:174.

70 Ding T, Yan F, Cao S, Ren X. Regulatory B cell: new member of immunosuppressive cell club. Human Immunol. 2015;76:615-21.

71 Fllatreau S. Regulatory functions of B cells and regulatory plasma cells. Biomed J. 2019 Aug;42:233-42.

72 Mauri C, Blair PA. Regulatory B cells in autoimmunity: developments and controversies. Nat Rev Rheumatol. 2010;6:636-43.

73 Mauri C, Bosma A. Immune regulatory function of B cells. Annu Rev Immunol. 2012;30: $221-41$

74 Mizoguchi A, Bhan AK. A case for regulatory B cells. J Immunol. 2006;176:705-10.

75 Flores-Borja F, Bosma A, Ng D, Reddy V, Ehrenstein MR, Isenberg DA, et al. CD19+CD24hiCD38hi B cells maintain regulatory $\mathrm{T}$ cells while limiting $\mathrm{TH} 1$ and $\mathrm{TH} 17$ differentiation. Sci Transl Med. 2013;5: 173 ra123.

76 Wei B, Velazquez P, Turovskaya O, Spricher K, Aranda R, Kronenberg M, et al. Mesenteric B cells centrally inhibit CD4+ T cell colitis through interaction with regulatory $\mathrm{T}$ cell subsets. Proc Natl Acad Sci U S A. 2005;102: 2010-5.

77 Wan J, Xing S, Ding L, Wang Y, Gu C, Wu Y, et al. Human-IgG-neutralizing monoclonal antibodies block the SARS-CoV-2 infection. Cell Rep. 2020 Jul 21;32:107918.

78 Rogers TF, Zhao F, Huang D, Beutler N, Burn $\mathrm{A}, \mathrm{He} \mathrm{W}$-t, et al. Isolation of potent SARS$\mathrm{CoV}-2$ neutralizing antibodies and protection from disease in a small animal model. Science. 2020;369:956-63. 
79 Chen X, Pan Z, Shuai Yue S, Fei Yu F, Zhang J, Yang Y, et al. Disease severity dictates SARS-CoV-2-specific neutralizing antibody responses in COVID-19. Signal Transduct Target Ther. 2020;180:5.

80 Quinti I, Lougaris V, Milito C, Cinetto F, Pecoraro A, Mezzaroma I, et al. A possible role for B cells in COVID-19? Lessions from patients with agammaglobulinemia. J Allergy Clin Immunol. 2020;146:211.

81 Sorensina A, Moratto D, Chiarini M, Paolillo C, Baresi G, Foca E, et al. Two X-linked agammaglobulinemia patients develop pneumonia as Covid-19 manifestation but recover. Ped Allrgy Immunol. 2020 Jul;31(5):565-9.
82 Myets I, Bucciol G, Quinti I, Neven B, Fisher A, Seoane E, et al. Coronavirus disease 2019 in patients with inborn errors of immunity. J Allergy Clin Immunol. 2020;32(5):1704-13.

83 Tirado SMC, Yoon K-J. Antibody-dependent enhancement of virus infection and disease. Viral Immunol. 2003;16:69-86.

84 Quinlan BD, Mou H, Zhang L, Guo Y, He W, Ojha A, et al. The SARS-CoV2-receptorbinding domain elicits a potent neutralizing response without antibody-dependent enhancement. bioRxiv. 2020.04.10.03641.8202.
85 Gao Q, Bao L, Mao H, Wang L, Xu K, Yang $\mathrm{M}$, et al. Development of an inactivated vaccine for SARSCoV-2. Science. 2020 Jul 3; 369(6499):77-81.

86 Duan K, Liu B, Li C, Zhang H, Yu T, Qu J, et al. Effectiveness of convalescent plasma therapy in severe Covid-19 patients. Proc Natl Acad Sci U S A. 2020;117:9490-6.

87 Li L, Zhang W, Hu Y, Tong X, Zheng S, Yang $\mathrm{J}$, et al. Effect of convalescent plasma therapy on time to clinical improvement in patients with severe and life-threatening COVID-19 a randomized clinical trial. JAMA. 2020 Aug 4; 324(5):460-70. 